\title{
造血幹細胞移植患者の廃用症候群に対する 理学療法効果について
}

\section{The Effect of Physiotherapy on Hematopoietic Stem Cell Transplantation Patients’ Disuse Syndrome}

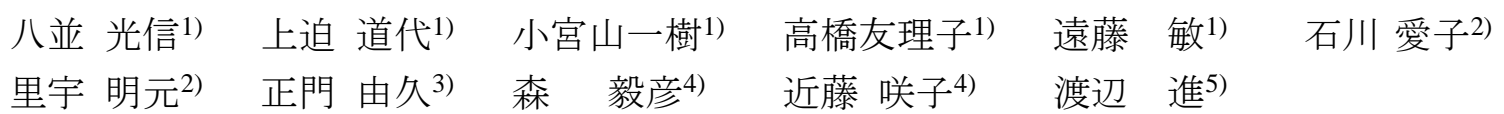

MitsUNOBU YATSUNAMI, RPT ${ }^{1)}$, MichIYo KAMISAKO, RPT ${ }^{1)}$, IKKI KOMIYAMA, RPT ${ }^{1)}$, YURIKO TAKAHASHI, RPT ${ }^{1)}$, SATOSHI ENDO, RPT ${ }^{1)}$, AIKo ISHIKAWA, MD²), MEIGEN LIU, MD ${ }^{2)}$, YoshiHISA MASAKADO, MD $^{3)}$,

TAKEHIKO MORI, MD'), SAKIKO KONDO, Nrs'), SUSUMU WATANABE, MD ${ }^{5)}$

1) Department of Rehabilitation of Keio University Hospital: 35 Shinanomachi, Shinjuku-ku, Tokyo 160-0016, Japan. TEL \& FAX +81-3-3354-1358

2) Department of Rehabilitation Medicine,Keio University School of Medicine

3) Keio University Tsukigase Rehabilitation Center

4) Department of Hematology Medicine, Keio University School of Medicine

5) Kawasaki University of Medical Welfare

Rigakuryoho Kagaku 20(2): 133-138, 2005. Submitted Dec. 16, 2004. Accepted Feb. 5, 2005.

ABSTRACT: The purpose of this study was to examine the effect of physiotherapy on the disuse syndrome in were hematopoietic stem cell transplantation patients' bioclean room treatment period. The subjects 17 of 35 patients who received hematopoietic stem cell transplantation in a period covering one year. Before and after transplantation, the patient's grip, muscle strength of lower extremity, endurance, amount of hemoglobin, and flexibility were evaluated. The patient did independent practice of muscle strength and stretching in the bioclean room every day. Furthermore, individual practice of muscle strength and stretching was usually carried out together with a physical therapist 3 times per week in the standing position. Compared with before transplantation, muscle strength, endurance, and flexibility fell after transplantation. The amount of Hb before and after transplantation was almost unchanged, and a low value was shown as compared with normal values. In spite of having performed physiotherapy during the bioclean room stay, the physical fitness before transplantation was unmaintainable. It was thought that the main causes were the activity restrictions in the bioclean room. In addition, the influence of adverse drug reaction, corpuscular reduction, undernutrition, and treatment related symptoms were also considered to have played a part.

Key words: hematopoietic stem cell transplantation, disuse syndrome, physiotherapy

要旨: 本研究の目的は, 造血幹細胞移植患者の無菌室治療期間中における廃用症候群へ対する理学療法の効果を検討 したものである。対象は，1年間に造血幹細胞移植を行った患者35名のうち，早期死亡を除いた18名であった。評価 は, 移植患者の握力・下肢伸展筇力・運動耐容能・Hb量・柔軟性について移植前後で行った。なお, 移植患者は, 毎 日，無菌室において筋力増強練習やストレッチングを自主練習した。さらに，週3回，理学療法士と主に立位で，筋力 増強練習とストレッチングを個別練習した。その結果，移植前と比べ移植後の筋力・運動耐容能・柔軟性の低下は顕

1) 慶應義塾大学病院リハビリテーション科：東京都新宿区信濃町35（†160-0016）TEL \& FAX 03-3354-1358

2) 慶應義塾大学医学部 リハビリテーション科 3) 慶應義塾大学月が瀬リハビリテーションセンター

4) 慶應義塾大学医学部 血液内科 5)川崎医療福祉大学 医療技術学研究科

受付日 2004年12月16日＼cjkstart受理日２005年2月5日 
著であった。Hb量は, 移植前後であまり変化はなく, 正常值と比較して低值を示した。今回, 無菌室滞在中も理学療法を行っ たにもかかわらず，移植前の筋力・運動耐容能・柔軟性を維持することができなかった。この原因としては，無菌室におけ る活動性の制約が大きいと考えられた。この他, 臨床的な観点から, 薬物の副作用・血球の回復状況・栄養状態・治療関連 症状等も考えられた。

キーワード : 造血幹細胞移植, 廃用症候群, 理学療法

\section{I. 緒 言}

造血幹細胞移植治療は, 白血病のみならず乳癌・腎癌・ 遺伝性疾患と多岐にわたって臨床応用が試みられてい る。特に, 成人の白血病患者の造血幹細胞移植は, 5 年生 存率が，約60\%に到達し，一定の成果をあげている。

しかし, 造血幹細胞移植治療の中核である無菌室内治 療中に多くの苦痛を伴う症状が生じる。一般的に, 治療 期間中の臨床症状としては, 口内炎による痛み・激しい 嘔吐・高熱・皮疹・下痢・浮腫などが，数週間続くこと になる。その結果，運動に対するモチベーションは低下 し臥床時間が増加寸る。

したがって, 理学療法の目的は, 無菌室内治療中に, 造血幹細胞移植患者の廃用性症候群を予防することであ る。本邦の造血幹細胞移植治療における理学療法関連の 先行研究は極めて少なく1-3), 成人を対象とした系統的な 理学療法プログラムと無菌室内治療期間中の廃用症候群 に対する理学療法効果の定量的な臨床報告はない。

我々は, 2001年より, 当院血液内科の造血幹細胞移植 チームへ参加し, 試行錯誤の結果, 理学療法プロトコー ルを開発し臨床に応用している。

本研究の目的は, 造血幹細胞移植患者の無菌室治療期 間中における廃用症候群に対する理学療法の効果を検討 することである。

\section{II. 対 象}

対象は，2002年1月から12月の1年間に造血幹細胞移植 を受けた患者35名中，移植後早期死亡者を除外し，移植 前後で評価を行った18名とした。なお，患者は，本研究 に参加する際, その目的・方法を担当内科医・リハビリ テーション医・理学療法士から十分な説明の後, 同意を 得た。

対象者の内訳は，男性13名（33.9 \pm 11.8 歳），女性5名 （39.0土18.8歳）であった。造血幹細胞移植（以下，移植 と略す）の対象となった原疾患は, 急性リンパ性白血病 2名・急性骨髄性白血病10名・T細胞白血病リンパ腫3名・ 非ホジキンリンパ腫3名であった。無菌室の滞在日数は, 45.4土17.2日であった。

\section{III. 方 法}

方法は，移植前後に以下の評価項目方法で行った。な お, 移植前評価は, 入院後1週間以内に行った。移植後評 価は, 無菌室から理学療法室へ処方変更になり1週間以内 に行った。

\section{1. 筋力について}

上肢筋力は，握力を指標にした。測定は，デジタル握 力計 (竹井機器社製Grid・D）で, 利き手より行い（全例 が右利き），2回施行して結果の良い方の值を記録した。 下肢筋力は, 膝の伸展筋力をリカンベント式筋力測定装 置（三菱電機社製Strength Ergo240）で，2回施行し結果の 良い方の值を記録した。測定モードは，アイソカイネ ティックモード（ペダル回転数 $50 \mathrm{r} / \mathrm{min} ・$ 測定回転回数 5 回）で，ピークトルク值・仕事量・脚力年齢を測定した。 測定姿勢は，背もたれ角度が座面に対して $110^{\circ}$ で，シー トの前後位置は, 右膝 $20^{\circ}$ 屈曲位になるよう調節した。 体幹は, 左右の肩からのシートベルトと腰ベルトで固定 した。ストレングスエルゴから出力される脚力年齢は, 20歳から85歳の健常者男女合計 900 名のデータを元に, 最 大トルク值の体重比と年齢から外挿法によって算出した 予測值である。

2. 運動耐容能について

運動負荷テストは, トレッドミル（Quintam 社製 StairMaster）で行った。運動負荷のプロトコールは, 平地 歩行で速度 $2 \mathrm{~km} / \mathrm{hr}$ から開始して, 3分毎に $1 \mathrm{~km} / \mathrm{hr}$ ずつ漸 増し, $6 \mathrm{~km} / \mathrm{hr}$ で終了する。血圧は運動負荷前・直後を電 子血圧計（テルモ社製ES-H51）で測定した。心拍数は, テレメーター心電図（日本光電社Life Scope LC）および テレメーター心拍計（キャノン製Polor S810）を用いた。 また，運動負荷テストの終了直前にBorgスケールを，患 者に提示して，自覚的運動強度を測定した。

なお, 我々は先行研究4)で, 本プロトコールにおける健 常者の平均最高心拍数が $114.2 \mathrm{bpm}, \mathrm{VO}_{2}$ は $19.7 \mathrm{ml} / \mathrm{kg} / \mathrm{min}$ で, $\dot{\mathrm{VO}}_{2} \max$ の約 $60 \%$ に相当することを報告した。 
表1＼cjkstart理学療法プロトコール

\begin{tabular}{|c|c|c|c|c|c|c|c|c|}
\hline & & \multicolumn{3}{|c|}{ 移植前 } & \multirow{2}{*}{\begin{tabular}{|l|} 
移植日 \\
$($ day 0$)$ \\
\end{tabular}} & \multicolumn{3}{|c|}{ 移植後 } \\
\hline 日程 & & 3週～4週而 & 1週前 & 1日前 & & 1週～4週後 & \multicolumn{2}{|r|}{ 2ヶ月から4ヶ月後 } \\
\hline 練習場所 & & 理学憭法室 & \multicolumn{4}{|c|}{ 無菌室 } & & 理学療法室 \\
\hline $\begin{array}{l}\text { 移植治療 } \\
\text { の内容 }\end{array}$ & \multicolumn{2}{|c|}{$\begin{array}{l}\text { 血液·CT·X線等の諸検 } \\
\text { 查および歯科等の治療 }\end{array}$} & $\begin{array}{l}\text { 全身放射線照射·超 } \\
\text { 大量化学療法 }\end{array}$ & $\begin{array}{l}\text { 休 } \\
\text { 息 }\end{array}$ & \multirow[b]{2}{*}{ 輸 } & $\begin{array}{l}\text { 移植閶連症状の治療や愛 } \\
\text { 性移植片対宿主病の予防 } \\
\text { おひひ治療等 }\end{array}$ & & $\begin{array}{l}\text { 慢性移植片対宿主の予防 } \\
\text { および治療、感染症の治 } \\
\text { 療等 }\end{array}$ \\
\hline $\begin{array}{l}\text { 理学療法 } \\
\text { の内容 }\end{array}$ & $\begin{array}{l}\text { 移 } \\
\text { 植 } \\
\text { 前 } \\
\text { 評 } \\
\text { 価 }\end{array}$ & $\begin{array}{l}\text { 無菌室内の自主練 } \\
\text { 習得 (ストレッチ } \\
\text { ング•セラバンドを用 } \\
\text { いた笳カ増強練 } \\
\text { 習)・・レレッドミル歩 } \\
\text { 行 }\end{array}$ & \multicolumn{2}{|c|}{$\begin{array}{l}\text { 自主練習および理学療法士 } \\
\text { と個別練習(立位にて、スト } \\
\text { レッチング・上肢·下肢の筋カ } \\
\text { 増強練習) }\end{array}$} & & $\begin{array}{l}\text { 自主練習および理学療法 } \\
\text { 士と個別練習(立位にて、 } \\
\text { ストレッチ肢・下肢 } \\
\text { の筋カ増強練習) }\end{array}$ & $\begin{array}{l}\text { 移 } \\
\text { 植 } \\
\text { 後 } \\
\text { 評 } \\
\text { 洒 }\end{array}$ & $\begin{array}{l}\text { ストレッチング·セラバンド } \\
\text { を用いた筋力増強練習·ト } \\
\text { レッドミル歩行 }\end{array}$ \\
\hline
\end{tabular}

表2 移植前後における筋力の変化

\begin{tabular}{|c|c|c|c|c|c|c|}
\hline \multirow[b]{2}{*}{ 筋力パラメータ } & \multicolumn{3}{|c|}{ 右 } & \multicolumn{3}{|c|}{ 左 } \\
\hline & $\begin{array}{c}\text { 移植前 } \\
\text { mean } \pm \mathrm{SD}\end{array}$ & $\begin{array}{c}\text { 移植後 } \\
\text { mean } \pm \mathrm{SD}\end{array}$ & 有意水準 & $\begin{array}{c}\text { 移植前 } \\
\text { mean } \pm \mathrm{SD}\end{array}$ & $\begin{array}{c}\text { 移植後 } \\
\text { mean } \pm \mathrm{SD}\end{array}$ & 有意水準 \\
\hline 握力（kgf） & $31.4 \pm 9.5$ & $25.1 \pm 8.9$ & $\mathrm{P}=0.00$ & $29.6 \pm 9.6$ & $23.0 \pm 8.7$ & $\mathrm{P}=0.00$ \\
\hline 握力（体重比） & $0.5 \pm 0.1$ & $0.4 \pm 0.1$ & $\mathrm{P}=0.00$ & $0.4 \pm 0.1$ & $0.3 \pm 0.1$ & $\mathrm{P}=0.02$ \\
\hline 下肢筋力（ピークトルク $\mathrm{N} ・ \mathrm{~m} ）$ & $131.5 \pm 45.5$ & $97.4 \pm 43.7$ & $\mathrm{P}=0.00$ & $127.1 \pm 42.4$ & $90 \pm 34.2$ & $\mathrm{P}=0.00$ \\
\hline 下肢筋力（体重比 N・m/kg） & $1.9 \pm 0.5$ & $1.6 \pm 0.5$ & $\mathrm{P}=0.00$ & $1.8 \pm 0.4$ & $1.5 \pm 0.4$ & $\mathrm{P}=0.00$ \\
\hline 下肢全仕事量（cal） & $1078.1 \pm 369.8$ & $794.2 \pm 327.5$ & $\mathrm{P}=0.00$ & $1021.9 \pm 336.1$ & $765.6 \pm 309.4$ & $\mathrm{P}=0.00$ \\
\hline 補足パラメーター & $\begin{array}{c}\text { 移植前 } \\
\text { mean } \pm \mathrm{SD}\end{array}$ & $\begin{array}{c}\text { 移植後 } \\
\text { mean } \pm \mathrm{SD}\end{array}$ & 有意水準 & & & paired $t$ test \\
\hline $\begin{array}{l}\text { 脚力年齢（歳）予測值 } \\
\text { 体重（kg） }\end{array}$ & $\begin{array}{l}52.7 \pm 12.2 \\
66.3 \pm 12.3\end{array}$ & $\begin{array}{l}66.2 \pm 14.4 \\
59.4 \pm 10.7\end{array}$ & $\begin{array}{l}\mathrm{P}=0.00 \\
\mathrm{P}=0.00\end{array}$ & & & \\
\hline
\end{tabular}

3. 血液データについて

一般血液データ中，特に運動遂行に影響を及ぼすへモ グロビン量を指標とした。

\section{4. 柔軟性について}

測定は，40 cmの台上に立ち，両足の踵をつけ足先を5 $\mathrm{cm}$ 開き，体幹をゆっくり屈曲する立位体前屈法を用い た。台面を0地点として, 両指先の最下端までの距離を記 録した。2回施行して良い方の值を記録した。

データの解析は，SPSS 11.0J for windowsを用いた。移 植前後の比較は, 対応のあるt検定を用いた。無菌室滞在 日数と筋力等の相関分析は, ピアソンの相関係数および $\rho$ 検定を用いた。検定は両側検定で行い, 有意確率を0.05 以下とした。

\section{IV. 理学療法プロトコール（表1）}

入院から無菌室へ移行するまでの理学療法室における
移植前理学療法は, ストレッチングと筋力強化を, 理学 療法士の監視と指導下で20分から30分間行った。さらに, トレッドミルで，予測最大心拍数の $60 \%$ を目標心拍数と して，20分間の歩行練習を行った。

前処置から移植後にドナーの骨髄が生着し，造血機能 が回復するまでの無菌室内理学療法は，移植前に習得し た自主練習と週3回の理学療法士による15分〜20分間の 個別練習を行った。個別練習は，基本的に立位で行い, 頸部・体幹・上肢・下肢のストレッチングと筋力強化を 行った。

\section{V. 結 果}

1. 移植前後の筋力について（表2）

移植前後の握力は，右移植前 $31.4 \pm 9.5 \mathrm{kgf} ・$ 移植後 25.1 $\pm 8.9 \mathrm{kgf}$, 左移植前 $29.6 \pm 9.6 \mathrm{kgf} \cdot$ 移植後 $23.0 \pm 8.7 \mathrm{kgf}$ で, 平均 $21.2 \%$ の有意な筋力低下を認めた $(\mathrm{P}=0.00)$ 。非利き 手より利き手の方が，筋力低下率が大きかった。また， 
表3＼cjkstart移植前後における運動負荷テスト結果

\begin{tabular}{lccc}
\hline 心機能パラメーター & $\begin{array}{c}\text { 移植前 } \\
\text { mean } \pm \mathrm{SD}\end{array}$ & $\begin{array}{c}\text { 移植後 } \\
\text { mean } \pm \mathrm{SD}\end{array}$ & 有意水準 \\
\hline 運動耐容速度 $(\mathrm{km} / \mathrm{hr})$ & $4.7 \pm 1.0$ & $4.0 \pm 1.0$ & $\mathrm{P}=0.03$ \\
運動耐容時間 $(\mathrm{min})$ & $13.8 \pm 3.0$ & $12.0 \pm 3.2$ & $\mathrm{P}=0.03$ \\
安静時心拍数 $(\mathrm{bpm})$ & $86.5 \pm 16.8$ & $101.6 \pm 10.0$ & $\mathrm{P}=0.00$ \\
安静時収縮期血圧 $(\mathrm{mmHg})$ & $114.4 \pm 13.1$ & $108.2 \pm 13.7$ & $\mathrm{P}=0.14$ \\
安静時二重積 & $9895.1 \pm 2356.4$ & $10960.1 \pm 1445.6$ & $\mathrm{P}=0.07$ \\
負荷後心拍数 (bpm) & $139.4 \pm 23.9$ & $151 \pm 12.3$ & $\mathrm{P}=0.02$ \\
負荷後収縮期血圧 (mmHg) & $137.8 \pm 20.3$ & $122.4 \pm 18.6$ & $\mathrm{P}=0.04$ \\
負荷後二重積 & $19035.1 \pm 4591.0$ & $18592.8 \pm 3315.7$ & $\mathrm{P}=0.75$ \\
負荷後自覚的運動強度 & $13.5 \pm 1.7$ & $15.1 \pm 1.6$ & $\mathrm{P}=0.01$ \\
\hline
\end{tabular}

移植前の握力は，日本人の体力標準值 ${ }^{5)}$ と年齢別・性別で 比較して10〜20 kgf低かった。

下肢伸展筋力のピークトルク值は，右移植前131.5 $45.5 \mathrm{Nm}$ ・移植後 $97.4 \pm 43.7 \mathrm{Nm}$, 左移植前 $127.1 \pm 42.4 \mathrm{Nm} \cdot$ 移植後 $90.0 \pm 34.2 \mathrm{Nm}$ で, 平均 $27.6 \%$ の有意な筋力低下を 認めた $(\mathrm{P}=0.00)$ 。下肢伸展筋力の移植後の減少率は，握 力と比較して大きかった。脚力年齢は，移植前 $52.7 \pm 12.2$ 歳, 移植後 $66.2 \pm 14.4$ 歳で, 有意に高くなっていた $(\mathrm{P}=0.00)$ 。

\section{2. 移植前後の運動耐容能について（表3）}

トレッドミルによる運動耐容速度は移植前 $4.7 \pm 1.0$ $\mathrm{km} / \mathrm{hr}$, 移植後 $4.0 \pm 1.0 \mathrm{~km} / \mathrm{hr}$ と有意に低下した $(\mathrm{P}=0.03)$ 。 運動耐容時間も移植前 $13.8 \pm 3.0 \mathrm{~min}, 12.0 \pm 3.2 \mathrm{~min}$ と有意 に低下した（P=0.03）。自覚的運動強度は，移植前13.5土 1.7 ，移植後 $15.1 \pm 1.6$ と有意に上昇した（P=0.01）。心機 能の負荷を反映する二重積（心拍数 $\times$ 収縮期血圧）は, 安静時, 移植前9895.1 \pm 2356.4 , 移植後10960.1 \pm 1445.6 と 増加傾向にあった（P=0.07）。しかし，負荷後の二重積は 差が認められなかった。

3. 移植前後のへモグロビン量について

男性のへモグロビン量は，移植前 $10.1 \pm 1.9 \mathrm{~g} / \mathrm{dl}$, 移植 後 $8.8 \pm 0.6 \mathrm{~g} / \mathrm{dl} （ \mathrm{P}=0.06 ）$ であった。女性のへモグロビン 量は，移植前 $9.4 \pm 1.8 \mathrm{~g} / \mathrm{dl}$, 移植後 $9.8 \pm 1.2 \mathrm{~g} / \mathrm{dl} （ \mathrm{P}=0.75 ）$ であった。移植前後で男性は，低下傾向が認められたが， 正常值と比較して，いずれも低值であった。

4. 移植前後の柔軟性について

立位体前屈は，移植前 $-1.1 \pm 11.7 \mathrm{~cm} ，$ 移植後 $-8.4 \pm$ $12.7 \mathrm{~cm}$ と有意に低下した（P=0.02）。しかし，筇力や持久
力に比較して，移植前より柔軟性が改善した者が6名（34 \%)いた。

5. 無菌室滞在日数に関わる要因について（図1）

無菌室滞在日数と年齢および移植後の体重 - 心拍数 ・ 血圧・自覚的運動強度・運動耐容速度・運動耐容時間・ 握力・下肢伸展筋力・立位体前屈について，相関分析を 行った。その結果, 移植後の体重 $\left(\mathrm{R}=-0.5, \mathrm{R}^{2}=0.2\right.$, $\mathrm{P}=0.05) \cdot$ 自覚的運動強度 $\left(\mathrm{R}=-0.5, \mathrm{R}^{2}=0.3, \mathrm{P}=0.03\right) \cdot$ 握力 $\left(\mathrm{r}=-0.6, \mathrm{R}^{2}=0.3, \mathrm{P}=0.03\right) \cdot$ 下肢伸展筋力 $(\mathrm{r}=-0.6$, $\left.\mathrm{R}^{2}=0.4, \mathrm{P}=0.01\right)$ が有意に相関していた。その他の変数は 無相関であった。

\section{VI. 考 察}

移植後の筋力低下の特徵は，上肢より下肢の方に影響 が大きく，ベッドレストの先行研究と類似した傾向が認

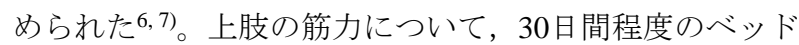
レストでも，あまり低下しないという報告もある8)。しか し，移植患者の上肢筋力は，約 $20 \%$ 低下しており，健常 者のベッドレストより廃用症状が進むことが示唆され た。

移植後の筋力低下は，無菌室滞在日数と関連性がある ことから，無菌室での低活動性が大きく影響しているも のと考えられた1)。移植患者は，健常者のベッドレストの 実験的拘禁状態に比べれば，無菌室内（約 $9 \mathrm{~m}^{2}$ ) でシャ ワー・トイレ等を自分で行っているが，物理的に歩行距 離はわずかで活動制限を受けている。また，自主練習や 理学療法士と個別練習を行ったが，移植前の筋力を維持 できなかった。今後, 練習頻度や強度に関して検討して いく必要があると考えられた9)。 

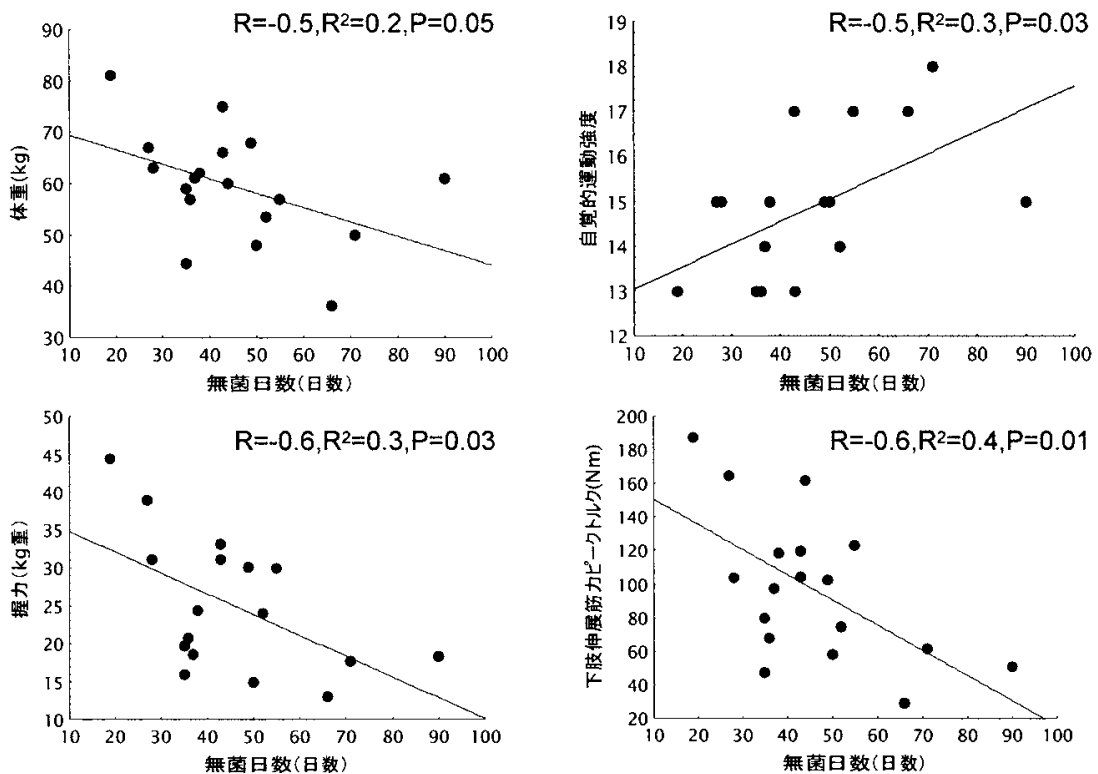

図1 無菌室滞在日数と移植後の体重・自覚的運動強度握力・下肢伸展筋力における相関

運動耐容能は，二重積に差がなかったものの，移植後 の運動耐容速度・時間の減少から, 低下しているものと 考えられた。Taylor10)に代表されるベッドレストの研究に よると，2週間から4週間のベッドレストにおける $\dot{\mathrm{VO}}_{2 \text { max }}$ の減少率は $12 \%$ から18\%であり，移植患者においても， 同様に $\dot{\mathrm{VO}}_{2}$ maxが減少していることが推測された。また, 移植後, 自覚的運動強度が一貫して高い点から，中枢性 疲労と下肢筋力低下による筋持久力の影響11)が考えられ た。移植後, 安静時・運動時共に, 患者の心拍は頻脈と なり，血圧の大きな上昇が認められなかった点は，ベッ ドレストの時間が長く，末梢血管抵抗の減少から，心臓 への還流量が低下し, 起立性低血圧症状と類似した状態 が示唆された12)。その他，免疫抑制剤の影響やへモグロ ビン量の低下による酸素運搬能との関連性 ${ }^{13)}$ も検討して いく必要があると考えられた。

運動耐容能の練習効果に関しては，トレッドミルで有 酸素運動を行い効果があったとする報告もあるが14)，無 菌室内において有酸素運動を実行することは困難であ り，移植後の理学療法室における継続的な有酸素運動練 習が重要であると考えられた。

柔軟性は，改善例が34\%あり，ギャッチアップや座位 時間の延長による背臥位でのベッドレスト時間の短縮や ストレッチングの励行が有効な方法と考えられた。

相関分析の結果から，無菌室での滞在日数が増加する と, 廃用症候群（特に下肢筋力）の進展が示唆された。
この原因として，無菌室における活動性の制約以外に， 薬物の副作用・血球の回復状況・栄養状態等が関与して いるものと考えられた。

今後の課題として, 無菌室滞在中の筋力や運動耐容能 の低下率を最小にする理学療法について改良を加えてい きたいと考える。

謝辞 本研究の一部は, 川崎医療福祉大学大学院医療技 術学部リハビリテーション学科後期博士課程の成14年度 プロジェクト研究助成により行われた。

\section{引用文献}

1) 豊倉 穣, 石田 暉, 林 克郎・他：骨髄移植のリハビリ テーション．PTジャーナル，1990, 24(8): 518-524.

2) 石田 睴, 加藤俊一, 林 克郎・他：骨髄移植後のリハビリ テーション.リハビリテーション医学，1991, 28(1): 11-18.

3) 星野敬子, 小山祐司, 矢部普正・他: 骨髄移植前後のリハビ リテーション．PTジャーナル，2000, 34(10): 691-696.

4) 八並光信, 上迫道代, 小宮山一樹・他 : 骨髄移植の機能低下 に関する検討．理学療法学，2003, 30(2): 142.

5) 東京都立大学体力標準值研究会 (編) : 新 $・$ 日本人の体力標 準值2000。誠信社，2000, pp160-165.

6) Suzuki Y, Iwamoto Y, Haruna S, et al.: Effect of 20day horizontal bed rest on mechanical efficiency during steady state exercise at mild-moderate work intensities in young subjects. J Gravit Pysiol, 1997, 4: S46-S52.

7) Leblanc AD, Schneider VS, Evans HJ, et al.: Regional changes in 
muscle mass following 17 weeks of bed rest. J Appl Physiol, 1992, 73: 2172-2178.

8) Greenleaf JE, Bernauer EM, Ertl AC, et al.: Isokinetic strength and endurance during 30-days $6^{\circ}$ head-down bed rest with isotonic and isokinetic exercise training. Aviat Space Environ Med, 1994, 65: 45-50.

9) Cunningham BA, Morris G, Cheney CL, et al.: Effects of resistive exercise on skeletal muscle in marrow transplant recipients Receiving total parenteral nutition. J Parenter Enteral Nutr, 1986, 10: 558-563.

10) Taylor HL, Henschel A, Brozek J, et al.: Effects of bed rest on cardiovascular function and work performance. J Appl Physiol, 1949,

\section{2: 223-239.}

11) 松永篤彦, 神谷健太郎, 齋藤正和・他：高齢者心疾患患者の 下肢筋力トレーニング目標值，心臓リハビリテーション， 2003, 8(1): 49-52.

12) 谷島一嘉 : ヘッドダウンベッドレストの生理. 臨床スポーツ 医学, 1993, 10(1): 5-11.

13) 堀井 昭, 犬飼道夫 : 人体総へモグロビン量からみた全身持 久力の研究. 体育学研究, 1972, 16: 215-221.

14) Dimeo F, Bertz H, Finke J, et al.: Aerobic exercise program for patients with haematological malignancies after bone marrow. Transplantation, 1996, 18: 1157-1160. 